\title{
DLL3 Gene
}

National Cancer Institute

\section{Source}

National Cancer Institute. DLL3 Gene. NCI Thesaurus. Code C104254.

This gene is involved in both notch-mediated signaling and neurogenesis. 